\title{
The epizootiology of pebrine, one of the great scourges of sericulture.
}

\author{
Tosihiko Hukuhara* \\ Faculty of Agriculture, Tokyo University of Agriculture and Technology, Fuchu, Tokyo, Japan
}

\begin{abstract}
The pathogen of pebrine is transmitted to a host either vertically or horizontally. Vertical transmission may arise in two distinct ways depending upon whether the passage of the pathogen occurs on the surface of the egg or within the ovary of the mother moth. Horizontal transmission occurs only in the larval stage. The most frequent source of infection in this stage is that which occurs when feces from infected larvae contaminate the food and are thus ingested by healthy larvae in the same colony. Sanitation and disease-free stock are the principal strategies of pebrine prevention.
\end{abstract}

Keywords: Epizootiology, Pebrine, Bombyx mori, Nosema bombycis.

\section{Introduction}

The silkworm is a monophagous insect, feeding only on the leaves of the mulberry tree. The fortunes of the silkworm and the mulberry tree are indissolubly associated, and when man steps in and patronizes the union between the two in order to get cocoons, there results an industry called sericulture. In the mid-nineteenth century, French sericulture suffered extensive damages due to a silkworm disease known as pebrine [1]. In the afflicted area, silkworm eggs did not hatch or gave rise to languishing larvae, the majority of which died prematurely. Few silkworms that managed to reach the moth stage produced deficient eggs which reproduced the same phenomena. Sericulturists knew by experience that the choice of healthy eggs was essential for successful cocoon harvest.

Scientific research on pebrine was initiated in 1850's. French and Italian scientists noted the presence of numerous oval corpuscles in various tissues of sick silkworms [2,3]. Swiss scientists considered the corpuscle to be yeastlike fungus and gave it the present name Nosema bombycis [4,5]. Louis Pasteur, who entered the field of microbial disease in animals by studying pebrine, recommended sericulturists to use only the eggs laid by mother moths with no corpuscles in their tissues [6,7]. The purpose of this article is to review the epizootiology of pebrine and to explore the relationship between epizootiology and actual disease management in sericulture.

\section{Life Cycle of the Pathogen}

$N$. bombycis belongs to the family Nosematidae of the phylum Microsporida [8]. Once ingested by silkworm larva, $N$. bombycis spores ("corpuscles" of Pasteur's day) are stimulated to germinate in the larval midgut. The germinating spore injects its germ into a cell of the midgut epithelium through a tubule ejected from the spore [9]. The germ multiplies intracellularly by binary fission. Finally, sporogony is initiated to produce oval and pyriform spores. The former spores serve for transmission between hosts, while the latter spores serve to spread the infection within the same host [10]. Pyriform spores inject their germ into neighboring host cells. Repetition of this cycle results in the systemic infection of the host.

Spores are present in carcasses, excreta (feces, regurgitated gut juice, meconium) and detached parts (egg shells, exuviae and scales) of pebrinized silkworms [11]. They survive in the external environment for many years unless they are dehydrated, heated or exposed to sunlight $[12,13]$. Thus, there may be very distant contact in time between the source host and the host subsequently infected. Alternate host insects of $N$. bombycis may also serve as the source of infection [14]. Moreover, some carnivorous non-host animals such as insect, fishes and birds may play a role in the dissemination of the pebrine pathogen, for $N$. bombycis spores remain infectious after being passed through their intestinal tract [15].

\section{Vertical Transmission}

The passage of the pathogen occurs either on the surface of the egg or within the ovary of the mother moth. The former mode of transmission occurs when emerging larva gnaws a hole through the chorion that has been contaminated with sporeladen meconium or scales of the mother moth [16]. Sericulture relies on prophylactic surface sterilization of eggs to prevent this mode of transmission.

Transovarial transmission occurs when female larvae are infected with the pathogen in the advanced (fourth and fifth) instars [17]. When infected larvae survived up to the pupal the infection spreads to the nurse cells within the ovariole. Soon thereafter oocytes acquire the pathogen from the associated nurse cell through the cytoplasmic bridge [18]. If mature eggs derived from these oocytes are fertilized, the embryos are infected either at the germ-band stage or at the reversal stage.

\section{Horizontal Transmission}

In horizontal transmission, the pathogen enters the silkworm body by way of the mouth and alimentary canal. Since pupae and moths do not take food at all, this mode of transmission occurs only in larval stage. In sericulture, it is a set routine that thousands of larvae are reared collectively on the same rearing 
bed [19]. The most frequent source of infection is that which occurs when feces from infected larvae contaminate the food and are thus ingested by healthy larvae in the same colony. It takes a certain number of spores to overpower the larval body defenses and initiate infection. The number of spores necessary for successful infection increases as the larval instar is advanced [20]. Mulberry leaves may also be contaminated through human activities such as the harvest, storage and feeding because rearer's clothes, bedding and accommodations are often contaminated with spores [21,22].

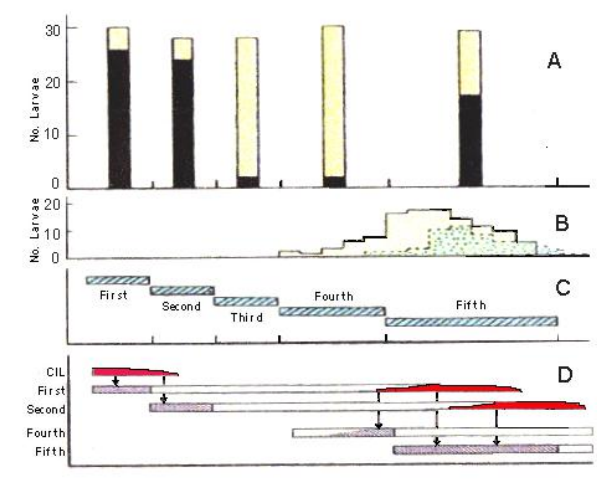

Figure 1. Spread of pebrine infection in a mixed culture of 32 congenitally infected larvae (CIL) and 300 healthy larvae [23,24]. (A). Prevalence of pebrine among 30 sample larvae that have been reared during either one of the five instars in the mixed culture. The histograms show the number of perinized (black) and healthy (yellow) larvae. (B). Frequency distribution of larvae excreting spores in their feces among 30 sample larvae that have been reared either during the first (open) or the second (green) instar. (C). Relative time lengths of five instars of healthy larvae. (D). Hypothetical model of the spread of infection. Congenitally infected larvae gradually decrease in number, emitting spore-laden feces (red). The pathogen is transmitted to healthy larvae in the first or second instar (arrow). The newly infected larvae (purple) begin to emit spore-laden feces in the fourth or fifth instar and succumb to pebrine before pupation.

When congenitally infected larvae and healthy larvae are present on the same rearing bed, the risk of horizontal transmission is high in the first, second and fifth instar but low in the third and fourth instar (Figure 1A-D). Congenitally infected larvae in the colony excrete spores into their feces soon after hatching, giving rise to the infection of healthy larvae in the first and second instars (Figure 1D). These lavae emit spore-laden feces in the advanced instars (Figure 1B), which results in the high rate of horizontal transmission during the fifth instar. Larvae that have been infected in the fourth or fifth instar survive up to the moth stage to become the parents of congenitally infected progeny.

\section{Pebrine-Free Stock}

Experiences gained during the past one and half century of sericulture have highlighted the importance of pebrine-free stock in the success of a rearing program. Under the ordinary sanitation regime, this approach alone may be adequate for the prevention of pebrine. The method that Pasteur proposed to obtain pebrine-free stocks assured sericulturists against extensive loss in cocoon yield: larvae derived from the stocks rarely died before cocooning even if they were infected during the rearing. It was unfortunate that French sericulturists did not have the expertise and appropriate facilities to put Pasteur's method into practice. This circumstance facilitated the creation of a new profession, that of egg producers [25]. They entrusted many peasants to start small-scale rearing of a specific silkworm variety. The harvested cocoons from individual farms were transported to the egg-production center where all the procedures of egg production including the microscopic inspection of the mother moths were conducted. Pasteur's method has been widely used up to this day in many sericultural countries to produce pebrine-free stocks [26].

\section{Conclusion}

For economic reasons, the object of pebrine management is not the eradication of the pathogen but stable reduction of its population to a level no longer important economically. The management is more population than individual oriented. Therapy of individual silkworms is not undertaken because of the economics involved. Sanitation and disease-free stock are the principal strategies for the prevention of pebrine. The main objective of these measures is to stop or at least minimize the spread of infection during the early larval instars. The use of resistant varieties is attractive from the managerial and economic standpoints because it requires no action during rearing. When genetic resistance is so high as to completely prevent pathogenesis, there will be no initial disease to start an epizootic. The amount of research being accomplished on this aspect is sadly out of balance with that being conducted on the pathogen.

\section{References}

1. de Quatrefages A. Essai sur 1'histoire de la sériciculture et sur la maladie actuelle des ver a soie. Paris: Victor Masson 1860.

2. Guérin-Méneville FE. Ėtude sur les maladies des vers à soie. Bull Soc Nation Central d'agricul. France. 1850;2:251-9.

3. Cornalia E. Monografia del gelso (Bombix mori Linn). Milano: Tipografia di Giuseppe Bernardoni di Gio 1856.

4. Lebert H. Ueber die Pilzkrankheit der Fliegen und die neueste in Oberitalien herrschende Krankheit der Seidenraupen mit Parasitenbildung, nebst einer Zusammenstellung der wichtigsten pflanzlichparasitischen Krankheiten, welche von Insekten und Myriapoden bekannt sind. Arch. Pathologische Anatomie Physiologie . Virchow. 1857;12:144-57.

5. von Nägeli C. Ueber die neue Krankheit der Seidenraupe und verwandte Organismen. Bot Zeitung Jahrg. 1857;15:760-1.

6. Pasteur L. Sur l'application de la méthode de M. Pasteur pour vaincre la pébrine. Annales scientifiques de l'École normale supérieure. 1872;2(I):1-9. 
7. Hukuhara T. Pasteur and the Silkworm Disease. Osaka \& Tokyo: Parade Books 2011.

8. Sprague V, Becnel JJ, Hazard EI. Taxonomy of the phylum Microsporidia. Crit Rev Microbiol. 1992;18:285-395.

9. Ohshima K. On the function of the polar filament of Nosema bombycis. Parasitology. 1937;29:220-4.

10. Iwano H, Ishihara R. Dimorphic development Nosema bombycis spores in gut epithelium of larvae of the silkworm, Bombyx mori. J Sericult Sci Japan. 1979;249-56.

11. Iwabuchi H, Mitani K. Studies on the source of infection of pebrine. Sangyo-Koshujo Shiken-Seiseki. Tokyo. 1913;48:67-138.

12. Hayashi Z, Nagama S, Sakamoto U, et al. The survival tests of pebrine corpuscles. Tokyo Sangyo Kosyujo Shiken Seiseki. 1912;46:157-223.

13. Ohshima K. Method of gathering and purifying active spores of Nosema bombycis and preserving them in good condition. Annot Zool. Japan. 1964;37:94-101.

14. Hirose Y. The wing of wild insects parasitized by Nosema bombycis and its role as a source of infection to the silkworm. Sansi-Kenkyu. 1979;110:111-5.

15. Kajitani K. Studies on the source, and the route, of infection of pebrine. Yamanashiken Sanshu Seizojo Seiseki Hokoku. 1919;1:171-212.

16. Iwabuchi H. Popular Silkworm Pathology. Tokyo. Meibundo 1908.

17. Ohshima K. Maternal and peroral infections of Nosema bombycis. In Ohshima K. (Ed.). Experimental Design on a Sampling Inspection Method of Pébrine Control Utilizing the Nature Characterized by Early Eclosion of Diseased Silkworm Moths. Tokyo: Bunkensha. 1976;53-70.

18. Iwabuchi H, Mitani K. On the germinal transmission of the corpuscle of pebine. Tokyo Sangyo-Koshujo Shiken Seiseki. 1913;48:1-65.
19. Hukuhara T, Murakami T, Nishide T. Introduction to Sericology (Revised Edition). Dainihon Sanshi-kai. Tokyo. 1992.

20. Fujiwara T. Infectivity and pathogenicity of Nosema bombycis to larvae of the silkworm. J Sericult Sci Japan. 1979;48:376-80.

21. Mitani K. Survey of the dissemination of pebrine spores. Aichiken Gensanshu Seizosho Jiseki Hokoku. 1914; $1: 167-88$.

22. Akita G. On the distribution of pebrine parasites of the silkworm. Sanshi-Kaiho. 1936;45:34-40.

23. Ishihara R, Fujiwara T. The spread of pebrine within a colony of the silkworm, Bombyx mori (Linnaeus). J Invertebr Pathol. 1965; 7:126-31.

24. Fujiwara T. Pebrine. In Sanshi-no-Hikari (Ed) Encyclopedia of the Pests of the Silkworm and the Mulberry Tree. Sanshi-no-Hikari. Tokyo. 1973;185-90.

25. Rebouillon A. Pratique des soins sanitaires à apporter dans la confection des graines de vers à soie. In Paillot $\mathrm{A}$, Rebouillon A (Eds). Les Maladies du Ver à Soie. Alès Stat Recherch Sericicol. Bulletin technique séricicole. 1945;5:27-53.

26. Ganga G. Comprehensive Sericulture. New Delhi. Oxford \& IBH Publishing Co. 2003.

\section{*Corresponding to}

Tosihiko Hukuhara

Professor Emeritus

Tokyo University of Agriculture and Technology

Fuchu, Tokyo, Japan

E-mail: tosihiko@biglobe.Jp 